\title{
Proposta de classificação do tecnógeno para uso no mapeamento de áreas de risco de deslizamento
}

\section{Technogenic classification proposal for use in landslide risk mapping}

\author{
Fabrício Araujo Mirandola $^{\mathrm{ab}}$, Eduardo Soares de Macedo ${ }^{\mathrm{ac}}$ \\ ${ }^{a}$ Instituto de Pesquisas Tecnológicas do Estado de São Paulo - IPT \\ babricio@ipt.br, cesmacedo@ipt.br
}

\begin{abstract}
RESUMO
Este trabalho coloca em discussão aspectos relativos ao acréscimo de uma proposta de classificação do tecnógeno, ao mapeamento de feições, depósitos e vetores tecnogênicos, à análise da carta de eixos de escoamento superficial e à setorização do tecnógeno ao método usual de elaboração de mapeamentos de risco. Como área-piloto para a elaboração dos mapeamentos de risco de deslizamento foi selecionada a favela Real Parque, em São Paulo, SP. Uma carta de risco foi elaborada com base no método usual, e a outra foi elaborada com base nos parâmetros utilizados na primeira carta, porém com a inclusão da análise do tecnógeno. Conclui-se que a inserção da análise do tecnógeno na elaboração da carta aperfeiçoou a análise do risco de deslizamento, aumentando o detalhe nas observações de campo e possibilitando a identificação de novos setores, os quais apresentam graus de risco mais elevados do que aqueles observados pelo método usual.
\end{abstract}

Palavras-chave: Tecnógeno; Classificação; Carta de Risco; Deslizamento.

\begin{abstract}
This work sets up a discussion on aspects related to the addition of a proposal for the classification of the Technogene to the mapping of features, deposits and technogenic vectors, to the analysis of the letter of superficial outflow axes and the sectorization of the technogene to the usual method of elaboration of risk mapping. As a pilot-area for the elaboration of the landslide risk mappings the selected place was the slum called Real Parque in São Paulo. A risk letter was elaborated based on the usual method and another one was elaborated based on the former one, but also considering a technogenic approach. It's possible to conclude that the insertion of the technogenel analysis to the risk mapping enhanced the risk analysis, giving more detailed information for field observation and allowing the identification of new sectors of risk, which usually presents higher degrees of risks that those observed by the usual method.
\end{abstract}

Keywords: Technogene; Classification; Risk Map; Landslide.

\section{Introdução}

Nos dias atuais, o cenário mundial mostra um crescente aumento no número de áreas com risco geológico e, portanto, um maior número de pessoas expostas a ele. Isto se deve: 1) à urbanização desordenada, que afeta significativamente todos os aspectos do planejamento, desenvolvimento e gestão das sociedades humanas; 2) à alta densidade populacional, uma das causas da degradação ambiental urbana, produzindo um meio ambiente próprio, em grande parte construído, alterando o meio ambiente global; e 3) ao crescente empobrecimento da população, que, pela necessidade de morar, é forçada a criar e viver em assentamentos precários urbanos, os quais apresentam problemas relacionados à legalidade da propriedade, deficiência dos serviços de infraestrutura urbana e oferta insuficiente de equipamentos públicos, podendo vir a apresentar a ocorrência de processos de instabilização associados a movimentos de massa.
O surgimento destes assentamentos se dá ao longo dos anos, sendo uma relação entre o processo de urbanização e o crescimento e empobrecimento populacional. Em princípio, na formação de uma cidade, devido à “cultura” de morar em locais planos, a população passa a ocupar áreas que apresentam maior facilidade para a construção de moradias e outras edificações. Ao longo dos anos, as ocupações tendem a migrar para as periferias devido ao grande crescimento populacional, gerando a expansão a partir das áreas centrais ou com condições mais favoráveis a serem construídas. Esta passagem para áreas periféricas, por vezes, leva a população a ocupar terrenos desfavoráveis para a construção de moradias, muitas vezes de baixa renda, como se observa nos grandes centros urbanos brasileiros. Esta população não dispõe de recursos técnicos e financeiros, o que, somado à ausência de uma cultura de uso e ocupação de morros, acarreta na ocupação precária destes terrenos.

Esse processo de expansão das áreas urbanas tem ocorrido na maioria das cidades brasileiras. Isto 
aumenta o número de vítimas potenciais e os possíveis prejuízos econômicos ocasionados pelos movimentos de massa, despertando a necessidade da utilização de uma ferramenta, como o zoneamento de risco geológico. Este classifica qualitativa e quantitativamente as áreas que apresentam risco geológico de movimentos de massa, entre outros, auxiliando na elaboração de cartas de risco, o que facilita o diagnóstico e a caracterização do problema, além da indicação de intervenções adequadas ao controle e gerenciamento desses riscos.

O zoneamento e as cartas de risco geológico de deslizamento são amplamente utilizados na gestão de risco, porém se isentam de considerar as modificações causadas pelo homem; ou seja, não utilizam informações e observações mais detalhadas sobre o tecnógeno presente na área de estudo.

Este artigo coloca em discussão alguns aspectos relativos à utilização de uma proposta de classificação do tecnógeno; ao mapeamento de feições, depósitos e vetores tecnogênicos; à análise da carta de eixos de escoamento superficial; e à setorização do tecnógeno para a elaboração de cartas de risco geológico de deslizamento.

Ter-Stepanian (1988) já estabelecia a correlação entre os processos naturais, que advêm da ação de fatores geológicos, e os processos tecnogênicos, gerados direta ou indiretamente pela ação do homem. Desde então, novas concepções teóricas surgiram na área da geologia, onde o homem passou a ser considerado agente geológico, devido à sua ação transformadora sobre a natureza. Peloggia (1996) ressaltava que a ação transformadora do homem sobre a natureza e seu papel como agente geológico independente geravam alterações quantitativas e qualitativas nos processos de transformação da superfície do planeta. Estas alterações eram observadas principalmente nas áreas urbanas, onde processos como os deslizamentos eram intensificados direta ou indiretamente pela ação do homem. Essa ação constante e efetiva sobre a natureza potencializa a deflagração do processo, o qual poderia vir a atingir uma grande quantidade de moradias, causando danos econômicos e sociais.

Dada sua importância, as feições, depósitos e vetores tecnogênicos vêm sendo observados e estudados, apresentando características diversas, que não se enquadram nos grupos, categorias ou classes existentes. Sua gênese, distribuição, estrutura, característica textural e comportamento geomecânico são pouco estudados. Não bastasse a grande lacuna no conhecimento destes depósitos e feições, percebe-se que, com relação ao risco geológico de deslizamentos, trabalhos com a identificação, classificação, mapeamento e setorização do tecnógeno são quase inexistentes. Neste sentido, estes quatro elementos passam a ser de extrema importância no processo de elaboração de cartas de risco de deslizamentos.

Não considerar a ação do homem no meio urbano pode ser um fator responsável por futuros eventos em áreas já mapeadas pelos métodos usuais. Mirandola (2003), ao comparar os dados coletados em investigações geológico-geotécnicas com os dados obtidos por meio do modelo digital de elevação e a carta de declividade da área da favela Real Parque, na cidade de São Paulo, observou uma incongruência entre esses dados, pois tanto o modelo como a carta de declividade mostravam áreas com baixa declividade, sendo que estas mesmas áreas, em campo, apresentavam alta declividade, em função de modificações antrópicas, o que mostra como os parâmetros para a elaboração de cartas geotécnicas devem ter uma análise mais ampla, já que os componentes relacionados aos fenômenos induzidos e de caráter localizado não são contemplados.

Isso enfatiza a necessidade de um olhar mais crítico, sendo imprescindível a análise conjunta dos condicionantes geológico-geotécnicos e das feições, depósitos e vetores tecnogênicos, pois somente desta maneira teremos uma representação fidedigna dos riscos relativos a deslizamentos presentes na área de estudo.

\section{Conceituações e principais classificações existentes sobre Tecnógeno e depósitos tecnogênicos}

Quanto às classificações referentes aos depósitos tecnogênicos, Chemekov (1983) distingue três séries principais: subaérea, subaquosa e subterrânea. Na primeira série são elencadas onze categorias singulares, definidas em função da gênese, composição e morfologia. Distinguem-se, assim, depósitos de aterramento e obras de terra, de deposição em reservatórios, rejeitos de mineração, dragagem, assoreamento de canais, camadas arqueológicas, etc.

Ter-Stepanian (1988) classifica os depósitos tecnogênicos de forma mais genérica, afirmando que estes são marcados por grande variedade, feições diferenciadas, diversidade de composição e grande variação de espessura. O autor enfatiza que tais depósitos caracterizam uma classe genética independente, embora possam ser traçadas analogias com depósitos naturais.

Fanning \& Fanning (1989) procuram demonstrar a aplicabilidade da classificação dos "solos altamente influenciados pelo homem”, proposta por estes, para os depósitos tecnogênicos. Esta classificação contempla as seguintes categorias:

a) Materiais úrbicos (do inglês urbic): trata-se de detritos urbanos, materiais terrosos que contêm artefatos manufaturados pelo homem moderno, frequentemente em fragmentos, como tijolos, vidro, concreto, asfalto, pregos, plástico, metais diversos, pedra britada, cinzas e outros, provenientes, por exemplo, de detritos de demolição de edifícios, com pouco ou nenhum lixo orgânico.

b) Materiais gárbicos (do inglês garbage): são depósitos de material detrítico, rico em lixo orgânico, de origem humana e que, apesar de conterem artefatos em quantidades muito 
menores que a dos materiais úrbicos, são suficientemente ricos em matéria orgânica para gerar metano em condições anaeróbicas.

c) Materiais espólicos (do inglês spoil): materiais terrosos escavados e redepositados por operações de terraplanagem em minas a céu aberto, rodovias e outras obras civis. Incluem-se aqui também os depósitos de assoreamento induzidos pela erosão acelerada. Seja como for, os materiais contêm muito pouca quantidade de artefatos, sendo assim identificados pela expressão geomórfica não natural, ou ainda por peculiaridades texturais e estruturais em seu perfil.

d) Materiais dragados: materiais terrosos provenientes da dragagem de cursos d’água e comumente depositados em diques, em cotas topográficas superiores às da planície aluvial.

Oliveira (1990) propõe a classificação geral dos depósitos tecnogênicos em três tipos genéticos:

a) Construídos (resultantes diretos da ação humana, como aterros, corpos de rejeito etc.).

b) Induzidos (resultantes de processos naturais modificados ou intensificados pela ação humana, como depósitos de assoreamento, aluviões modernos etc.).

c) Modificados (solos ou depósitos naturais alterados em sua constituição por componentes tecnogênicos, como efluentes, adubos etc.).

Nolasco (2002) introduz uma quarta categoria à classificação de Oliveira (1990), os depósitos retrabalhados, englobando quaisquer depósitos tecnogênicos que sofreram a ação de agentes naturais, resultando na imposição das estruturas de outro agente geológico, sem intervenção humana (e sem, também, descaracterizar o depósito em si), como a erosão ou o solapamento de um aterro.

Peloggia (1999) propõe a seguinte classificação para os depósitos tecnogênicos:

a) Depósitos de primeira ordem ou geração, a partir da sistemática geral proposta por Oliveira (1990), que diferencia depósitos construídos, induzidos e modificados.

b) De segunda ordem, depósitos remobilizados (por exemplo, depósitos de fundos de vale formados por deslizamentos de aterros) e retrabalhados(propostos por Nolasco (2000, 2001); por exemplo, aterros ravinados.

Esta classificação integrada dos depósitos, proposta por Peloggia (1999), leva em conta a aplicação sequencial dos parâmetros gênese (referente aos processos geradores), composição (material constituinte ou "litologia”), estrutura (arranjo espacial), forma de ocorrência (localização ou expressão fisiográfica) e ambiente tecnogênico de deposição.

Bertê (2000) apresenta estudos demonstrando a aplicabilidade da classificação dos depósitos tecnogênicos construídos (aterros urbanos, aterros sanitários e lixões), elaborada por Oliveira (1990), nos depósitos localizados no município de Porto Alegre.
Fujimoto (2001) identifica feições antropogênicas e as correlaciona com a classificação dos táxons elaborados por Ross (1992). A autora identificou formas de relevo que foram induzidas ou criadas a partir da ação antrópica, como as formas em planícies fluviais tecnogênicas e flúvio-lacustre tecnogênicas, fazendo a relação do surgimento dessas formas com o processo de crescimento urbano na cidade de Porto Alegre.

Nolasco (2002) apresenta outra classificação para os depósitos tecnogênicos:

a) Diretos: depósitos construídos (realizados pelo homem, como, por exemplo, aterros); induzidos (realizados pela ação humana com o uso planejado de outro agente; por exemplo, depósitos resultantes de deslizamentos provocados em minerações).

b) Indiretos: resultantes da soma de ações do agente homem, sem intencionalidade, com as de outros agentes (por exemplo, leques de deslizamento de encosta em áreas urbanas por acúmulo de lixo e peso de construções).

Juntamente a esta classificação, a autora citada verifica a existência de uma complexidade nas transformações provocadas pelo homem como agente geológico, pois estes processos se manifestam a curto, médio e longo prazo, com abrangências locais, regionais e em todo o planeta, como as mudanças globais produzidas pelo homem. Deste quadro complexo resulta a grande dificuldade de classificação dos ambientes específicos de formação dos depósitos tecnogênicos. Pode-se, entretanto, simplificar a questão, considerando inicialmente os sistemas do ambiente sedimentar tecnogênico como aqueles identificados com as principais atividades humanas: os sistemas sedimentares mineiros, industriais, urbanos, rurais, etc.

Horn Filho (2003), ao fazer a caracterização e compartimentação geológica, geomorfológica e geográfica da província costeira do estado de Santa Catarina, com ênfase na planície costeira, identifica os depósitos tecnogênicos como marcos estratigráficos formados principalmente por aterro e rejeitos industriais, incluindo dessa maneira o Quinário como idade e o Tecnógeno como forma de depósito, na estratigrafia geral da Província Costeira catarinense.

Bertê (2004) afirma que os depósitos tecnogênicos caracterizam uma classe genética independente, embora sejam encontradas semelhanças com os depósitos naturais. Estas geralmente estão desvinculadas dos locais onde se formaram e apresentam artefatos diversos, além de expressar um momento histórico do desenvolvimento tecnológico. É no espaço urbano que se verifica mais facilmente sua presença; no entanto, sua distribuição, gênese, estrutura e dinâmica interna ainda não são conhecidas suficientemente, e sua presença, assim como a dos depósitos superficiais do Quaternário, raramente é mencionada em mapeamentos ou trabalhos de 
caracterizações geotécnicas, geológicas, geomorfológicas e de solos.

Segundo Oliveira et al. (2005),os estudos sobre a forma de ocorrência e a composição (classificação) de depósitos tecnogênicos permitem caracterizar a história do uso do solo, responsável por sua gênese e pelas transformações sucessivas do meio físico até os dias atuais. Além da forma de ocorrência, várias características do seu conteúdo, como estratificação, composição textural e palinológica, além da presença eventual de artefatos, constituem evidências de diferentes fases históricas do uso do solo na bacia, combinadas com os eventos de chuva do período. Além do depósito, o horizonte de solos soterrados constitui importante elemento para completar a história do ambiente anterior à ação tecnogênica.

Seja como for, o ponto fundamental na questão da classificação (ordenação e hierarquização dos tipos de depósitos) é ter claro, na caracterização de um depósito tecnogênico, como sendo um registro geológico gerado pela atividade humana, o conceito de depósito correlativo. Parece aqui adequada a definição de que o depósito correlativo corresponda a determinada ação específica; ou seja, não existiria, ao menos naquela forma e expressão, sem uma ação que pode ser, assim, determinada e especificada e, uma vez que isto seja feito, a caracterização do depósito decorre dela, mesmo que faltem os atributos litológicos diferenciadores (Peloggia \& Oliveira 2005).

As classificações citadas anteriormente, mesmo que idealizadas de forma individual, podem ser integradas, como observado por Peloggia (2003), que relata que um depósito composto por uma ampla gama de artefatos, tais como papel, vidro, metal, plástico, borracha, tecidos e outras fibras e material orgânico de origem vegetal e animal, cuja presença possibilita a geração de gás metano em condições anaeróbicas, pode ser classificado como depósito tecnogênico construído urbano do tipo gárbico, segundo as classificações de Oliveira (1990) e de Fanning \& Fanning (1989).

A necessidade da criação de uma nova proposta de classificação para o tecnógeno surgiu, pois entre as classificações observadas na bibliografia, nenhuma apresentou um enfoque direto relacionando à questão do risco geológico de deslizamento versus tecnógeno. Obviamente, a base conceitual para formação e desenvolvimento desta proposta tem por base todo estado da arte das propostas até hoje sugeridas, sendo de grande importância para a criação do link entre o tecnógeno e o risco geológico de deslizamentos com foco nos assentamentos precários urbanos.

\section{Proposta para Classificação do Tecnógeno}

Elaborou-se uma classificação que tem o intuito de ser utilizada em áreas de assentamentos urbanos precários. Esta classificação tem como base três grupos distintos, como observado no quadro 1.

Ressalta-se que a divisão nestes três grupos havia sido observada por Zorzato \& Peloggia (2000), porém sem a intenção de classificar o tecnógeno, apenas descrevendo uma análise das situações de risco geológico urbano no município de São Paulo quanto a deslizamentos cadastrados.

Quadro 1: Grupos propostos para classificação do tecnógeno

\begin{tabular}{c}
\hline Grupos \\
\hline Feições tecnogênicas \\
Depósitos tecnogênicos \\
Vetores tecnogênicos \\
\hline
\end{tabular}

Nesta análise, o grupo feições tecnogênicas é identificado na seguinte descrição:

“A primeira situação a ser distinguida é a alteração artificial do equilíbrio geomorfológico das encostas, com a consequente geração de escorregamentos induzidos, envolvendo depósitos superficiais (como os colúvios) ou maciços saprolíticos estruturados” (Zorzato \& Peloggia 2000).

O grupo depósitos tecnogênicos, na seguinte descrição:

“A segunda é a criação de depósitos de baixa estabilidade geotécnica. Enquanto os colúvios e outros depósitos superficiais são os materiais básicos para os escorregamentos em encostas naturais de regiões tropicais; nas encostas urbanas frequentemente são coberturas tecnogênicas, referidas frequentemente como solos antrópicos, lançamentos de lixo ou, mais especificamente, coberturas remobilizadas.” (Zorzato \& Peloggia 2000).

E o grupo vetores tecnogênicos, nesta descrição:

“A terceira situação é a alteração do regime hídrico e do escoamento das águas superficiais e subterrâneas. A alteração dos níveis freáticos tem sido verificada como agente deflagrador de escorregamentos em maciços naturais e tecnogênicos, enquanto que a impermeabilização superficial das bacias, intensificando o escoamento pelos talvegues, vai associar-se às áreas de risco de baixada, sujeitas a serem atingidas pelo alagamento ou pelo processo de solapamento de margens dos canais onde, com frequência, os materiais erodidos também são depósitos tecnogênicos.” (Zorzato \& Peloggia 2000).

\section{Grupo 1 - Feições Tecnogênicas}

Este grupo identifica as modificações resultantes da ação humana que não propiciam a geração de depósitos (apesar de, indiretamente, a execução de cortes poder gerar depósitos de aterro lançado), mas a geração de uma feição geométrica, o corte ou talude de corte.

Outro fator para a inclusão do corte na classificação se deve à grande ênfase dada pelos autores que trabalham com tecnógeno aos depósitos gerados pela ação tecnogênica, como observado nos trabalhos de Chemekov (1983), Ter-Stepanian (1988), Fanning \& Fanning (1989), Oliveira (1990), Nolasco (2002), Peloggia (1999), entre outros, sem considerar modificações de ordem geométrica.

No entanto, esta feição é de grande importância, pois é sabido que nas áreas de risco os maiores problemas se dão por deslizamentos deflagrados em taludes de corte, já que sua execução modifica por completo a dinâmica natural do terreno. Existe uma falsa 
percepção da população, a qual crê que um corte em talude é seguro, principalmente no caso de cortes em solos saprolíticos que apresentam grande competência quando não saturados. Porém, estes cortes são executados em período de estiagem, quando se mostram íntegros e passam uma falsa impressão de segurança, pois tendem a apresentar problemas apenas nos períodos de chuva, quando saturados. Devido a esta percepção errônea, os cortes são executados com grandes dimensões e inclinações próximas a $90^{\circ}$, para que o proprietário do terreno ganhe mais área na construção de sua moradia e utilize menos o aterramento, pois os moradores têm a percepção de que os aterros são mais instáveis.

$\mathrm{Na}$ realidade os depósitos tecnogênicos são mais instáveis que os cortes, porém sua instabilização apresenta, normalmente, menos risco aos moradores do que a instabilização de um corte, pois em geral suas dimensões são menores, gerando menor volume de massa mobilizada quando da deflagração de deslizamentos. Além disso, segundo observações de campo, as moradias normalmente apresentam pequena porção construída sobre estes depósitos, o que não ocasiona grandes danos estruturais, como observado nas fotos 1 e 2. Quando da deflagração destes processos o cenário observado é a frequente exposição das fundações das moradias e, por vezes, o colapso da parede atingida.

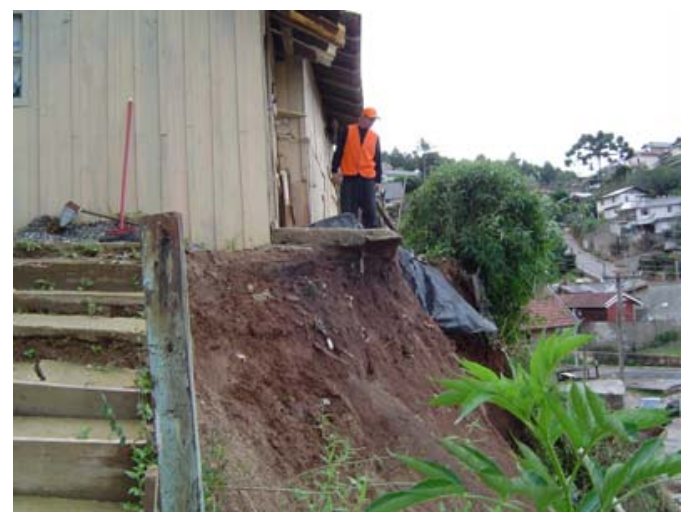

Foto 1: Detalhe de uma ruptura em aterro ocorrida no município de Campos do Jordão (SP). Notar como a estrutura da moradia não foi atingida. Fonte: Arquivo IPT.

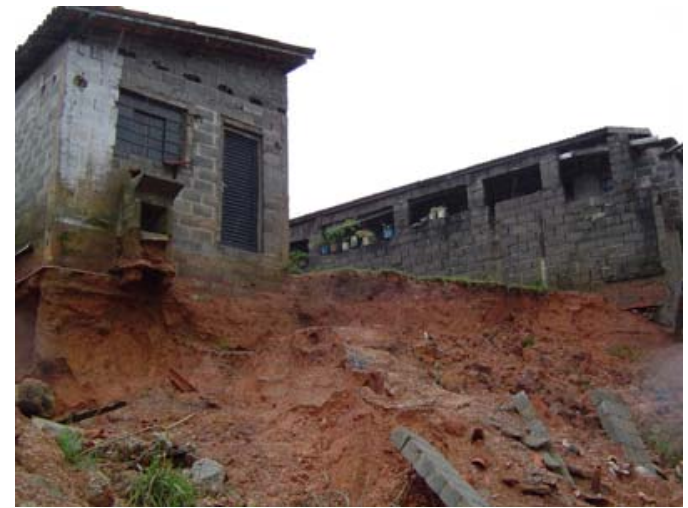

Foto 2: Detalhe da ruptura de um aterro nos fundos de uma moradia no município de Tapiraí (SP). Notar como não há danos à estrutura da moradia. Fonte: Arquivo IPT.
Nos cortes, o processo de deflagração é rápido e mais destrutivo. A falsa segurança que sua execução passa aos moradores faz com que construam suas moradias muito próximas aos mesmos, aumentando a possibilidade de atingimento caso ocorra a deflagração de um processo de deslizamento. É comum observar, principalmente nos assentamentos precários urbanos, que os moradores constroem seus dormitórios nos fundos das moradias, sempre próximos aos cortes, acreditando estar mais seguros. Porém, isto aumenta a probabilidade da ocorrência de óbitos ou de feridos, pois quando os deslizamentos ocorrem à noite, estes cômodos tendem a estar ocupados (fotos 3 e 4).

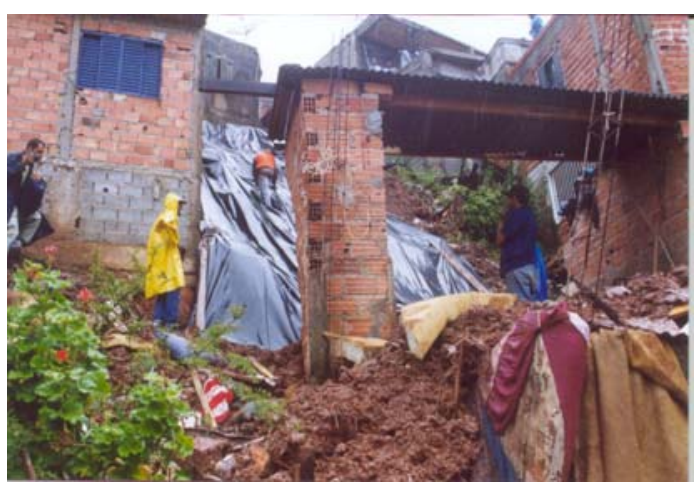

Foto 3: Moradia localizada em assentamento precário em Taboão da Serra (SP), completamente destruída por uma ruptura em corte. Fonte: Arquivo IPT.

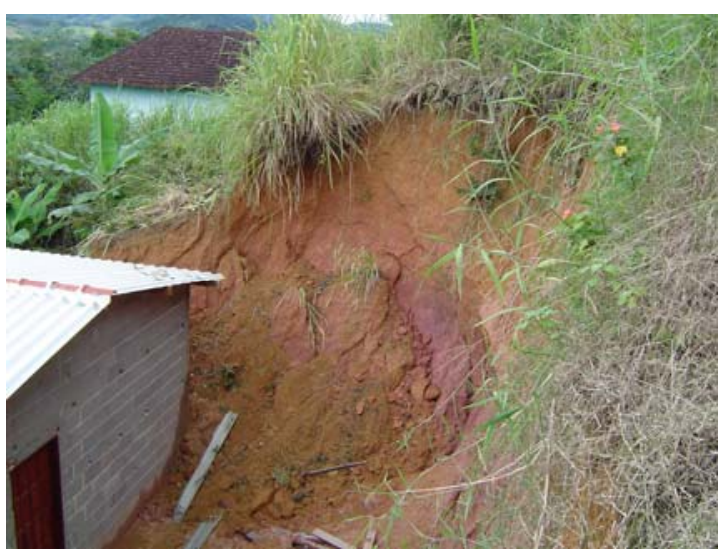

Foto 4: Detalhe do material mobilizado na ruptura de um corte ocorrido no município de Guarujá (SP). O cômodo dos fundos desta moradia foi parcialmente destruído. Fonte: Arquivo IPT.

É sabido que cortes com pequena altura são menos suscetíveis a apresentar rupturas do que cortes maiores. Sendo assim, propõe-se uma subdivisão, levando-se em conta três alturas. Primeiramente, a pequena altura, que reflete cortes pouco suscetíveis a algum tipo de ruptura, mas caso esta ocorra, não devem causar dano social ou econômico. A média altura, com cortes mais suscetíveis a apresentar algum tipo de ruptura, podendo causar dano social ou econômico. E a grande altura, que reflete cortes muito suscetíveis a apresentar algum tipo de ruptura, ou cortes que já apresentam histórico de ruptura, podendo causar sérios danos sociais e econômicos.

O modelo da classificação pode ser observado no quadro 2. 
Antropoceno - Tecnógeno

Quadro 2: Modelo de classificação para as feições tecnogênicas

\begin{tabular}{cc}
\hline Feição Tecnogênica & Altura \\
\hline Corte & Pequena Altura \\
Corte & Média Altura \\
Corte & Grande Altura \\
\hline
\end{tabular}

Esta classificação não propõe intervalos numéricos para as alturas propostas. Estes dados devem ser obtidos de forma observacional na área de estudo em questão, já que a altura dos cortes presentes em cada área está intimamente ligada ao relevo e à geologia locais.

\section{Grupo 2 - Depósitos tecnogênicos}

Por mais que os depósitos tecnogênicos sejam estudados, fica difícil a criação de uma classificação menos generalista que as existentes, pois comumente são marcantes as heterogeneidades composicional e granulométrica destes depósitos em função dos tipos de solo que os compõem, em geral provenientes da própria encosta, de movimentações de terra, ou até trazidos de outras localidades. Isso sem contar a quantidade e os tipos de artefatos, entulhos e até mesmo lixo doméstico presentes. Esta heterogeneidade demonstra, mesmo que empiricamente, que as propriedades geotécnicas destes depósitos são muito variáveis, tanto de um local para outro como dentro de um mesmo depósito, não permitindo uma análise quantitativa laboratorial, pois não é possível a aquisição de amostras e dados representativos.

Desta maneira, é proposta uma classificação mais relacionada às questões do risco geológico de deslizamento, na tentativa de se evitar a generalização das classificações existentes.

Este grupo, denominado Depósitos Tecnogênicos, foi dividido segundo os tipos de depósitos mais comuns e presentes nos assentamentos precários urbanos. Foram elencados três tipos de depósito: depósito de solo, depósito de lixo e depósito de entulho. Cada depósito pode conter mais de um tipo de material; portanto, a denominação será dada a partir do material que tem maior presença na matriz. Assim, um depósito com mais de $50 \%$ de solo pode conter lixo e entulho em sua composição, porém sua nomenclatura será "depósito de solo".

A importância da identificação e presença dos depósitos de solo já foi indicada no item anterior. A identificação e presença dos depósitos de lixo e entulho também é um fator importante, principalmente em áreas urbanas, pois em muitos casos o lixo e entulho acumulados nas encostas podem vir a deflagrar processos de deslizamento, principalmente devido à falta de coesão e estruturação que estes apresentam, sendo mais suscetíveis ao processo do que os cortes ou depósitos mais homogêneos. Em casos extremos, estes depósitos podem vir a deslizar, apresentando as mesmas consequências desastrosas de um deslizamento de depósito de solo ou em corte. Muitos dos deslizamentos ocorridos nas favelas de São Paulo têm sido gerados pela mobilização de lixo e de entulho acumulados nas encostas, e não pela mobilização do solo ou rocha.

Assim como no grupo Feições Tecnogênicas, a altura foi o critério adotado para diferenciar depósitos com a mesma composição. Depósitos com pequena altura são menos suscetíveis a apresentar rupturas do que depósitos com alturas maiores. Sendo assim, propõe-se uma subdivisão, levando-se em conta três alturas. Primeiramente, a pequena altura, que reflete depósitos pouco suscetíveis a algum tipo de ruptura, mas caso esta ocorra, não devem causar dano social ou econômico. A média altura, que reflete depósitos mais suscetíveis a apresentar algum tipo de ruptura, podendo causar dano social ou econômico. E a grande altura, que reflete depósitos muito suscetíveis a apresentar algum tipo de ruptura, ou aqueles que já apresentam histórico de ruptura, podendo causar sérios danos sociais e econômicos.

A classificação proposta pode ser observada no quadro 3.

Quadro 3: Modelo de classificação para os depósitos tecnogênicos

\begin{tabular}{cc}
\hline Depósitos Tecnogênicos & Altura \\
\hline Depósito de solo & Pequena Altura \\
Depósito de solo & Média Altura \\
Depósito de solo & Grande Altura \\
& \\
Depósito de lixo & Pequena Altura \\
Depósito de lixo & Média Altura \\
Depósito de lixo & Grande Altura \\
& \\
Depósito de entulho & Pequena Altura \\
Depósito de entulho & Média Altura \\
Depósito de entulho & Grande Altura \\
\hline
\end{tabular}

Esta classificação não propõe intervalos numéricos para as alturas propostas. Estes dados devem ser obtidos de forma observacional na área de estudo em questão, já que a altura dos depósitos presentes em cada área está intimamente relacionada à altura dos cortes presentes,ao relevo e à geologia locais.

\section{Grupo 3 - Vetores tecnogênicos}

O terceiro grupo foi criado com a intenção de enfatizar outras ações tecnogênicas que não resultam na geração de depósitos. Este grupo foi denominado Vetores tecnogênicos. No caso desta classificação, foram identificadas quatro ações principais, as quais ocorrem em diversos assentamentos urbanos precários e têm grande influência na deflagração de deslizamentos, tanto em cortes como em depósitos. Estas quatro ações estão relacionadas à presença da água e seu comportamento:

- Concentração de água pluvial e/ou servida em superfície, induzida pela ocupação;

- Lançamento de água servida em superfície;

- Vazamentos de tubulações;

- $\quad$ Presença de fossa.

Estas quatro ações são independentes entre si; ou seja, caso uma delas esteja presente na área em questão, não é necessário que as outras estejam, ou vice-versa. Sua presença ou ausência é determinada por 
observações de campo. A classificação proposta pode ser observada no quadro 4.

Quadro 4: Modelo de classificação para os vetores tecnogênicos

\begin{tabular}{cc}
\hline \multirow{2}{*}{ Vetores Tecnogênicos } & \multicolumn{2}{c}{ Presença } \\
\cline { 2 - 2 } & SIM NÃO \\
\hline Concentração & \\
Lançamento \\
Vazamento \\
Fossa \\
\hline
\end{tabular}

\section{Aplicação da proposta de classificação}

A aplicação da proposta para classificação do tecnógeno foi realizada na Área da Favela do Real Parque, situada na zona sul da cidade de São Paulo (figura 1), com base nos dados obtidos nas fichas de campo para mapeamento das feições, depósitos e vetores tecnogênicos presentes na área de estudo.

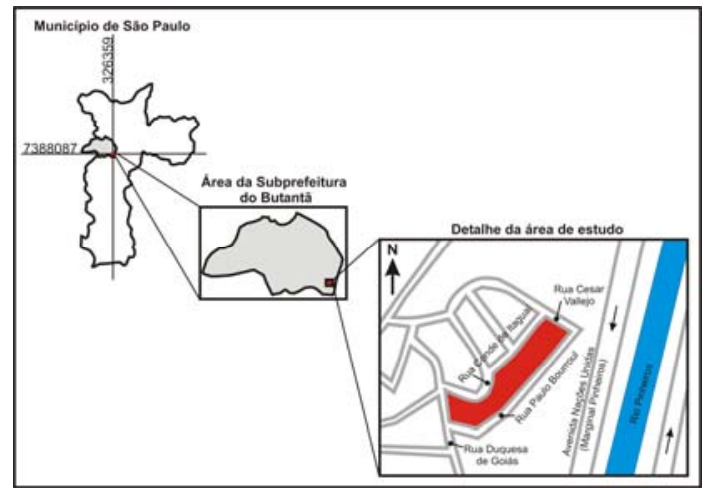

Figura 1: Localização da área de estudo com relação ao município de São Paulo

\section{Feições tecnogênicas}

Os dados sobre a altura dos cortes mapeados foram tabulados, possibilitando o estabelecimento de intervalos numéricos (quadro 5).

Quadro 5: Correlação entre o modelo de classificação para as feições tecnogênicas e os intervalos numéricos estabelecidos

\begin{tabular}{ccc}
\hline $\begin{array}{c}\text { Feição } \\
\text { Tecnogênica }\end{array}$ & Altura & Altura \\
\hline Corte & Pequena Altura & $<0,5 \mathrm{~m}$ \\
Corte & Média Altura & $0,5 \mathrm{a} 1,5 \mathrm{~m}$ \\
Corte & Grande Altura & $>1,5 \mathrm{~m}$ \\
\hline
\end{tabular}

Sendo assim, a classificação para os cortes é a seguinte:

- Cortes com altura $<0,5 \mathrm{~m}$ são pouco suscetíveis a algum tipo de ruptura, mas caso esta ocorra, não devem causar dano social ou econômico.

- Cortes com altura entre 0,5 e $1,5 \mathrm{~m}$ são mais suscetíveis a apresentar algum tipo de ruptura, podendo causar dano social ou econômico.

- Cortes com altura $>1,5$ m são muito suscetíveis a apresentar algum tipo de ruptura, ou cortes que já apresentam histórico de ruptura, podendo causar dano social ou econômico.

Ressalte-se que os dados numéricos aqui apresentados refletem a realidade observada na área de estudo e não devem ser tomados como padrão para outras áreas.

\section{Depósitos tecnogênicos}

Entre os depósitos tecnogênicos presentes na proposta de classificação, os mais observados na área de estudo foram os depósitos de solo. Os depósitos de lixo, embora poucos, estavam presentes. Os depósitos de entulho não foram observados, portanto não entram na classificação para a Favela Real Parque.

Os dados sobre a altura dos depósitos mapeados foram tabulados, possibilitando o estabelecimento de intervalos numéricos (quadro 6).

Quadro 6: Correlação entre o modelo de classificação para os depósitos tecnogênicos e os intervalos numéricos estabelecidos

\begin{tabular}{cc}
\hline Depósitos Tecnogênicos & Altura \\
\hline Depósito de solo & Pouca Altura \\
Depósito de solo & Média Altura \\
Depósito de solo & Grande Altura \\
& \\
Depósito de lixo & Pouca Altura \\
Depósito de lixo & Média Altura \\
Depósito de lixo & Grande Altura \\
\hline & \\
\hline Depósitos Tecnogênicos & Altura \\
\hline Depósito de solo & $<0,5 \mathrm{~m}$ \\
Depósito de solo & 0,5 a 1,5m \\
Depósito de solo & $>1,5 \mathrm{~m}$ \\
& \\
Depósito de lixo & $<0,5 \mathrm{~m}$ \\
Depósito de lixo & Não observado \\
Depósito de lixo & Não observado \\
\hline
\end{tabular}

Sendo assim, a classificação para os depósitos de solo é a seguinte:

- Depósitos de solo com altura <0,5m são pouco suscetíveis a algum tipo de ruptura, mas caso esta ocorra, não devem causar dano social ou econômico.

- Depósitos de solo com altura entre 0,5 e 1,5m são mais suscetíveis a apresentar algum tipo de ruptura, podendo causar dano social ou econômico.

- Depósitos de solo com altura $>1,5$ m são muito suscetíveis a apresentar algum tipo de ruptura, ou aqueles que já apresentam histórico de ruptura, podendo causar danos sociais ou econômicos.

A classificação para os depósitos de lixo é a seguinte:

- Depósitos de lixo com altura $\leq_{0,5 m}$ são pouco suscetíveis a algum tipo de ruptura, mas caso esta ocorra, não devem causar dano social ou econômico.

Ressalte-se que os dados numéricos aqui apresentados refletem a realidade observada na área de estudo e não devem ser tomados como padrão para outras áreas.

\section{Vetores Tecnogênicos}

Entre os vetores tecnogênicos presentes na proposta de classificação, o mais observado na área de estudo foi a concentração de água pluvial e/ou servida em superfície, induzida pela ocupação, presente em todos os pontos de controle. O vazamento de tubulações foi a 
segunda ação mais observada, aparecendo apenas uma vez a mais do que o lançamento de água servida em superfície. Não foram observadas fossas na área de estudo. Os resultados são mostrados no quadro 7.

Quadro 7: Quadro indicativo da presença ou ausência dos vetores tecnogênicos

\begin{tabular}{lll}
\hline \multirow{2}{*}{ Vetores Tecnogênicos } & \multicolumn{2}{l}{ Presença } \\
\cline { 2 - 3 } & SIM & NÃO \\
\hline Concentração & $\mathbf{X}$ & \\
Lançamento & $\mathbf{X}$ & \\
Vazamento & $\mathbf{X}$ & \\
Fossa & & $\mathbf{X}$ \\
\hline
\end{tabular}

Como o objetivo deste grupo na classificação é enfatizar a presença ou ausência destes quatro vetores, percebe-se, pela presença da concentração de água pluvial e/ou servida em superfície induzida pela ocupação, que a área encontra-se intensamente alterada quanto às linhas de drenagem naturais.

\section{Elaboração das cartas de risco a e b - parâmetros utilizados e descrição}

No zoneamento de risco, que segundo Cerri \& Amaral (1998) delimita as zonas homogêneas com relação ao grau de risco, são estabelecidas as classes de risco que, neste trabalho, encontram-se baseadas na metodologia nacional de mapeamento de risco (Ministério das Cidades/Instituto de Pesquisas Tecnológicas, 2007), que institui quatro níveis de risco: Baixo (R1), Médio (R2), Alto (R3) e Muito Alto (R4).

A partir do zoneamento, foram elaboradas duas cartas de risco para a mesma área, a fim de analisar os ganhos da aplicação da proposta de classificação do tecnógeno. Neste trabalho, o conceito de carta de risco segue o definido por Cerri \& Amaral (1998), sendo esta um instrumento que apresenta a distribuição, o tipo e o grau dos riscos geológicos, visando à gestão e prevenção dos riscos a ela associados.

A Carta de Risco A (figura 2) elaborada segundo o método usual para mapeamento de risco geológico de deslizamentos, baseado na metodologia nacional para mapeamento de áreas de risco de deslizamento e solapamento de margens de córregos elaborada pelo IPT (Ministério das Cidades/Instituto de Pesquisas Tecnológicas, 2007), levou em conta a análise da base topográfica da área de estudo, o modelo digital de elevação, a carta de declividade e as investigações geológico-geotécnicas de superfície.

Nesta carta, cada polígono desenhado representa uma moradia. O traçado das vielas não foi inserido na mesma, pois, mesmo com a fotografia aérea digital, a qual atinge a escala 1:1.000, não é possível a distinção destas na vetorização.

Segundo análise realizada, a área da Favela Real Parque foi dividida em três setores, conforme observado na figura 2. Em cada setor foram observados os condicionantes e indicadores associados aos processos existentes no local.

O setor 1A apresenta grau de risco baixo, conforme observado nas investigações geológico-geotécnicas. No setor, $65 \%$ das moradias são de madeira, das quais 50\% não apresentam nenhum tipo de drenagem superficial, $30 \%$ são precárias e $20 \%$ apresentam drenagem superficial satisfatória, evitando a concentração de água de chuva em superfície em mais da metade do setor. Este é o setor onde a água e o esgoto encontramse em melhores condições, com 50\% das moradias tendo esgoto ligado na rede coletora. Apenas $40 \%$ dos encanamentos de água e esgoto apresentam algum tipo de vazamento. A área não apresenta taludes de corte, pois sua maior declividade atinge o máximo de $5^{\circ}$. Existem muito aterros construídos para aplainar o terreno, facilitando a construção das casas, porém 85\% deles são compactados, o que diminui a possibilidade da deflagração de processos de deslizamento. Observam-se nos aterros não compactados feições que evidenciam solapamento, como trincas e pequenos degraus de abatimento, principalmente nos aterros localizados nas curvas das vielas, os quais são atingidos pela enxurrada, a qual é deflagrada pelas águas superficiais vindas de montante. Não existem grandes quantidades de lixo e entulho presentes no setor devido à proximidade do mesmo com a Rua Paulo Borroul, o que facilita a coleta. Outro fator que contribui para a limpeza do setor são as vielas pavimentadas, facilitando o deslocamento dos moradores. Não foram observados processos de instabilização no setor; porém, caso algum deles ocorra, espera-se que sejam relativos a deslizamentos em taludes de corte e/ou aterro. O setor $1 \mathrm{~A}$ foi caracterizado como de baixo risco, não apresentando nenhum parâmetro ou evento relevante com relação ao processo de deslizamento. $\mathrm{O}$ setor não apresenta histórico relativo à deflagração de processos de deslizamento e erosão, ressaltando-se apenas a presença de alguns pontos isolados onde as feições de solapamento deflagradas por enxurrada estão presentes. Os condicionantes geológico-geotécnicos predisponentes e o nível de intervenção no setor $1 \mathrm{~A}$ indicam baixa potencialidade para o desenvolvimento de processos de deslizamento. As condições observadas atingem o estágio menos crítico no grau de probabilidade de ocorrência de processos de instabilização do tipo deslizamento em encostas ocupadas. Mantidas as condições existentes, não se espera a ocorrência de eventos destrutivos no período de um ano.

O setor 2A é o que apresenta maior grau de risco, conforme observado nas investigações geológicogeotécnicas. Os dados indicam que $75 \%$ das moradias presentes no setor são de madeira, e nenhuma delas apresenta nenhum tipo de drenagem superficial nas proximidades, provocando a concentração de água de chuva em superfície. O esgoto é outro grande problema, pois $100 \%$ das moradias o lançam a céu aberto, e aproximadamente $60 \%$ do encanamento que leva o esgoto das moradias até vielas ou taludes apresenta algum tipo de vazamento. Foram observadas surgências na base do talude de corte e infiltrações nos aterros presentes na área, o que é tido como um sinal de maior predisposição à movimentação, pois a água é 
reconhecidamente o principal agente deflagrador de deslizamentos. Em geral, as moradias localizadas na base dos taludes distam cerca de 1metro dos mesmos, podendo ser atingidas no caso da ocorrência de deslizamento. Outras moradias são construídas na própria superfície do talude, com seus alicerces cravados no mesmo, sem a realização de um novo corte. Estas assemelham-se a "palafitas”, com relação ao método construtivo, ficando praticamente penduradas no talude. Existe grande quantidade de lixo e entulho no setor, e $100 \%$ das fichas apontando a presença destes. Também se observa na área o cultivo de banana e algumas hortaliças. As feições mais importantes são as evidências de movimentação na área, as quais estão presentes em grande quantidade neste setor. Constatou-se que $80 \%$ dos pontos visitados apresentam trincas nas moradias e no terreno, e 83\% apresentam degraus de abatimento. A inclinação de árvores, postes e muros atingiu 100\%, sendo observada em todos os pontos. Cicatrizes de deslizamentos foram observadas em $66 \%$ das fichas, o que indica que o setor já apresenta um histórico de deslizamentos. Foram observados processos de instabilização, tais como rastejo, deslizamento em depósito de encosta (lixo e/ou entulho), deslizamento de aterro e em talude de corte. Além destes processos ocorridos, espera-se a ocorrência de outros eventos relativos a deslizamentos em taludes de corte, aterro e depósitos de encosta (lixo e/ou entulho), além da continuidade do processo de rastejo. O setor $2 \mathrm{~A}$ já apresentou mais de uma ocorrência de deslizamento, em geral de pequeno porte, mobilizando solo, lixo e entulho, além do deslizamento nos depósitos de aterros não compactados. Este local apresenta sérios problemas devido ao seu acesso extremamente complicado. Para chegar ao local é necessário atravessar uma viela que se tornou uma verdadeira "galeria”, pois os moradores utilizaram os muros que delimitam a viela como apoio para as lajes de novas moradias, transformando a mesma numa passagem muito estreita, a qual apresenta alguns pontos com apenas $0,5 \mathrm{~m}$ de largura. Os condicionantes geológico-geotécnicos predisponentes e o nível de intervenção no setor $2 \mathrm{~A}$ remetem a uma potencialidade muito alta para o desenvolvimento de processos de deslizamento. As evidências de instabilidade são expressivas e estão presentes em grande número e/ou magnitude. Observa-se a ameaça tanto às moradias situadas na crista como na base dos taludes de corte e aterro. As condições observadas atingem o estágio mais crítico para a ocorrência de processos de instabilização do tipo deslizamento em encostas ocupadas. Mantidas as condições existentes, é muito provável a ocorrência de eventos destrutivos durante episódios de chuvas intensas e prolongadas, no período de um ano.

O setor 3A apresenta grau de risco médio, conforme observado nas investigações geológico-geotécnicas. Neste setor, 66\% das moradias são de madeira, 65\% não apresentam nenhum tipo de drenagem superficial nas proximidades e $35 \%$ apresentam drenagem precária, evitando a concentração de água de chuva em superfície em alguns pontos. Neste setor, o esgoto é um grande problema, uma vez que $60 \%$ das moradias o lançam a céu aberto e apenas $40 \%$ têm o esgoto ligado a uma rede coletora. Dos encanamentos que levam o esgoto das moradias até a viela ou a rede coletora, 50\% apresentam algum tipo de vazamento. A área possui taludes de corte de pequenas dimensões, com até $3 \mathrm{~m}$ de altura e pontos isolados com taludes apresentando $6 \mathrm{~m}$ de altura. As moradias apresentam em média $2 \mathrm{~m}$ de distância da base do talude e 3 a $4 \mathrm{~m}$ do topo. Não existe grande quantidade de lixo e entulho, pois a proximidade do setor com a rua Conde de Itaguaí facilita a coleta, além de grande parte das vielas ser pavimentada. O processo de instabilização ocorrido no setor foi um deslizamento em talude de corte. Além deste processo já ocorrido, espera-se a ocorrência de outros eventos relativos a deslizamentos em taludes de corte, aterro e natural. Com isso, o setor 3A é caracterizado como de médio risco, pois estão presentes parâmetros importantes, como alta declividade e presença de água significativa, com esgoto a céu aberto e concentração de água de chuva em superfície. Neste setor ocorreu um grande deslizamento no ano de 1994, junto à Rua Conde de Itaguaí, no limite superior analisado. Não houve vítimas neste evento, pois o deslizamento foi lento, e a população percebeu a movimentação horas antes da sua deflagração, ocorrida devido ao rompimento de uma adutora da Sabesp. Dias após o ocorrido, a prefeitura iniciou uma obra de contenção no local, onde foi construído um muro de arrimo de $6 \mathrm{~m}$. É recomendada a verificação periódica das condições de estabilidade dessa obra, pois existem moradias que seriam afetadas numa eventual instabilização da mesma. O maior problema observado no setor, e que se reflete em toda a favela, é a tipologia das moradias, construídas em sua maioria em madeira, além da grande quantidade de vielas sem pavimentação, o que auxilia a infiltração de água, acelerando o processo de deslizamento. Os condicionantes geológico-geotécnicos predisponentes e o nível de intervenção no setor 3A conferem a este grau médio para deflagração de deslizamentos. Não foram observadas evidências de movimentação, porém existe média potencialidade para deflagração de processos erosivos lineares associados ao sistema de drenagem superficial deficitário, afetando localmente as edificações. Mantidas as condições existentes, é pouco provável a ocorrência de eventos destrutivos durante episódios de chuvas intensas e prolongadas, no período de um ano.

A análise e a inter-relação destes dados possibilitaram a identificação de três setores de risco distintos, sendo: grau de risco baixo para o setor $1 \mathrm{~A}$, grau de risco muito alto para o setor $2 \mathrm{~A}$, e grau de risco médio para o setor 3A.

A Carta de Risco B (Figura 3) foi elaborada segundo método que leva em conta a análise da base topográfica da área de estudo, o modelo digital de elevação e a carta de declividade, como no método usual, e inclui a 
análise do mapeamento das feições, depósitos e vetores tecnogênicos, dos eixos de escoamento superficiais da área, da aplicação da proposta para classificação do tecnógeno e da carta de setorização do tecnógeno.

Nesta carta, cada polígono desenhado representa uma moradia. O traçado das vielas não foi inserido na mesma, pois, mesmo com a fotografia aérea digital, a qual atinge a escala 1:1.000, não é possível a distinção destas na vetorização. Segundo análise realizada, foram feitas modificações significativas com relação à Carta de Risco A, sendo acrescidos mais dois setores, conforme observado na figura 3. Em cada setor foram observados os condicionantes e indicadores associados aos processos existentes no local, além dos parâmetros principais, tanto para os cortes como para os depósitos, quais sejam, gênese de formação e altura.

O setor $1 \mathrm{~B}$ é o único onde os taludes de cortes não foram identificados, pois a área apresenta inclinação de no máximo $5^{\circ}$. É possível que existam tais cortes, porém devem apresentar altura inferior a $0,5 \mathrm{~m}$ e devem estar locados na parte dos fundos das moradias, protegidos superficialmente, o que dificulta sua identificação. Outro fator que dificulta a observação é que este setor apresenta alto grau de consolidação. Foram observados depósitos de solo lançado, sendo que a maioria apresenta altura inferior a $0,5 \mathrm{~m}$. Foram identificados poucos depósitos com altura entre 0,5 e $1 \mathrm{~m}$. Este setor se caracteriza por apresentar depósitos de solo lançado com altura inferior ou igual $0,5 \mathrm{~m}$, executados para servir de base para a construção das moradias, ou para nivelar as vielas. Os depósitos com altura superior a $0,5 \mathrm{~m}$ e inferior a $1,5 \mathrm{~m}$ estão situados em pontos próximos ao limite do setor, em uma zona de transição, onde é normal se observarem tais medidas. A concentração de água pluvial e/ou servida em superfície, induzida pela ocupação, é o vetor tecnogênico mais presente no setor. O lançamento de água servida em superfície foi observado em menor quantidade e não se observou o vazamento de tubulações, tampouco a presença de fossas. A maioria das moradias presentes no setor é de madeira. Metade das moradias não apresenta nenhum tipo de drenagem superficial e o restante apresenta drenagem satisfatória ou precária, o que auxilia a evitar a concentração de água de chuva em superfície em mais da metade do setor. Este é o setor onde a água e o esgoto encontramse em melhores condições. Não existe grande quantidade de lixo e entulho devido à proximidade do mesmo com a rua Paulo Borroul, o que facilita a coleta. Outro fator que contribui para a limpeza do setor são as vielas pavimentadas, facilitando o deslocamento dos moradores. O setor 1B não apresenta histórico relativo à deflagração de processos de instabilidade. Os condicionantes geológico-geotécnicos predisponentes e o nível de intervenção no setor $1 \mathrm{~B}$ indicam baixa potencialidade para o desenvolvimento de processos de deslizamento. As condições observadas atingem o estágio menos crítico no grau de probabilidade de ocorrência de processos de instabilização do tipo deslizamento em encostas ocupadas. Mantidas as condições existentes, não se espera a ocorrência de eventos destrutivos no período de um ano.

O setor 2B é o que apresenta o maior grau de risco. Este difere dos outros setores pois apresenta um talude de corte de grandes dimensões, o que lhe confere um caráter único. O talude em questão apresenta, aproximadamente, $10 \mathrm{~m}$ de altura por $20 \mathrm{~m}$ de extensão e sua inclinação varia de $80^{\circ}$ a $90^{\circ}$. Parte de sua superfície encontra-se coberta por depósitos de solo lançados, contendo lixo e entulho. Observam-se rupturas planares rasas em alguns trechos onde sua superfície é aparente. Na porção mais a leste do setor, são observados cortes menores, com altura variando de $1,5 \mathrm{~m}$ a $5 \mathrm{~m}$ e inclinação entre $70^{\circ}$ e $90^{\circ}$. Estes taludes foram executados para a ampliação da área do terreno. Alguns destes taludes também apresentam depósitos de solo sobre sua superfície. Foram observados depósitos com mais de $50 \%$ de solo na matriz, composto também por lixo e entulho. As alturas destes depósitos variam de $0,5 \mathrm{~m}$ a $6 \mathrm{~m}$, sendo que a maioria se encontra sobre a superfície do corte de grandes dimensões. O depósito de menor altura foi observado sobre o topo deste mesmo talude de corte. Depósitos de lixo também foram identificados. Em todos os casos, estes se encontram ou sobre os depósitos de solo lançados, ou sobre a própria superfície dos taludes, com uma altura média de $0,5 \mathrm{~m}$ e inclinação de aproximadamente $30^{\circ}$. Este setor se caracteriza por apresentar as maiores alturas, tanto em relação aos cortes como aos depósitos. Também é o único setor em toda a área da favela que apresenta depósitos de lixo. Das moradias presentes no setor, $75 \%$ são de madeira, e nenhuma apresenta nenhum tipo de drenagem superficial nas proximidades, o que auxilia na concentração de água pluvial em superfície. Em geral, as moradias localizadas na base dos taludes distam cerca de $1 \mathrm{~m}$ dos mesmos, podendo ser atingidas no caso da ocorrência de rupturas nos taludes ou caso o processo de rastejo dos depósitos não seja sanado. Outras moradias foram construídas com seus alicerces cravados na própria superfície do talude de corte ou nos depósitos de solo lançado presentes no setor. A concentração de água pluvial e/ou servida em superfície induzida pela ocupação e o lançamento de água servida em superfície são os vetores tecnogênicos mais presentes no setor, em $100 \%$ das fichas. O vazamento de tubulações foi observado em $75 \%$ das fichas, o que indica a grande presença de água no setor. O esgoto é outro grande problema, pois $100 \%$ das moradias o lançam a céu aberto. Foram observadas surgências d'água no contato entre a superfície do talude de corte de grandes dimensões e os depósitos tecnogênicos acima deste. Esta é uma indicação importante, já que a água é o principal agente deflagrador de deslizamentos, tanto em cortes como em depósitos, principalmente em depósitos de lixo. A presença de fossas não foi observada. As evidências de movimentação estão presentes em grande quantidade neste setor. Foram observadas trincas nas moradias e no terreno, degraus de abatimento e inclinação de árvores, postes e muros. 
Cicatrizes de deslizamentos também foram observadas, o que indica que o setor já apresenta um histórico de eventos. No setor $2 \mathrm{~B}$ observam-se rupturas de pequeno porte no talude de corte de grandes dimensões, além do processo de rastejo presente nos depósitos de solo lançados e lixos localizados sobre este. Este processo de rastejo é observado pelos moradores desde o ano de 2001. Um dos depósitos de solo da porção leste do setor já sofreu, no ano de 2002, a desestruturação por saturação d'água, o que resultou no seu colapso e na destruição de duas moradias. O talude de corte situado atrás de uma moradia reconstruída no local das duas casas destruídas, citadas anteriormente, sofreu ruptura planar rasa no ano de 2007, atingindo e destruindo parte dessa nova moradia. Os condicionantes geológico-geotécnicos predisponentes e a grande suscetibilidade à deflagração de processos de instabilidade dos cortes e depósitos tecnogênicos presentes no setor remetem a uma potencialidade muito alta para o desenvolvimento de processos de deslizamento. As evidências de instabilidade são observadas e estão presentes em grande número e/ou magnitude. Observa-se a ameaça tanto às moradias situadas na crista como na base dos taludes de corte e depósitos.

As condições observadas atingem o estágio mais crítico para a ocorrência de processos de instabilização em encostas ocupadas. Mantidas as condições existentes, é muito provável a ocorrência de eventos destrutivos durante episódios de chuvas intensas e prolongadas, no período de um ano.

O setor 3B é o maior setor identificado na área. Mesmo com grande extensão, os parâmetros observados se mantêm semelhantes. Os taludes de corte têm alturas variando entre $1 \mathrm{~m}$ e $1,5 \mathrm{~m}$. Acredita-se que a ocorrência de cortes seja maior do que o observado. Estes não são muito visíveis em campo pois devem estar locados na parte dos fundos das moradias, protegidos superficialmente, o que dificulta sua identificação. Outro fator que dificulta a observação é o fato de que este setor apresenta médio a alto grau de consolidação. Nos depósitos identificados no setor, foram observadas alturas que variam de $0,5 \mathrm{~m}$ a $1,5 \mathrm{~m}$. Nenhum depósito com alturas diferentes a este intervalo foi observado. Estes foram executados para servir de base para a construção de moradias ou nivelar as vielas, e em sua maioria apresentam proteção superficial, mesmo que precária. Suas inclinações variam de $5^{\circ}$ a $20^{\circ}$. A tipologia da construção das moradias do setor é mista. As moradias de madeira não apresentam nenhum tipo de drenagem superficial nas proximidades e quando apresentam, esta é precária, evitando a concentração de água pluvial em superfície somente em alguns pontos. As moradias apresentam, em média, $2 \mathrm{~m}$ de distância da base dos taludes de corte e 3 a $4 \mathrm{~m}$ do topo. A concentração de água pluvial e/ou servida em superfície induzida pela ocupação é o vetor tecnogênico mais presente no setor. O vazamento de tubulação foi observado, mas em pequeno número. $\mathrm{O}$ lançamento de água servida em superfície e a presença de fossas não foram observados. O setor 3B, assim como o setor $1 \mathrm{~B}$, não apresenta histórico relativo à deflagração de processos de deslizamento nos depósitos observados, porém a presença de cortes e a altura mais elevada dos depósitos são indicativos de que a suscetibilidade para ocorrência de processos de instabilização neste setor é maior do que no setor $1 \mathrm{~B}$. Os condicionantes geológico-geotécnicos predisponentes e o nível de intervenção no setor 3B conferem a ele um grau médio para deflagração de processos de instabilização nos cortes e nos depósitos tecnogênicos. As evidências de movimentação no setor são ínfimas ou não ocorrem. Mantidas as condições existentes, é pouco provável a ocorrência de eventos destrutivos durante episódios de chuvas intensas e prolongadas, no período de um ano.

O setor 4B é o que mais apresenta taludes de corte e depósitos de solo lançados, todos com alturas elevadas. Os taludes de corte têm alturas variando entre $1 \mathrm{~m}$ e 3,5m. Estes foram executados para acerto e ampliação do terreno para construção de moradias, já que a maior parte do setor encontra-se sobre um grande depósito de material mobilizado por um deslizamento ocorrido em 1994. A cicatriz de deslizamento resultante gerou um aumento na inclinação natural do terreno, sendo este o setor que apresenta a maior inclinação em toda a área. Isto não se reflete no mapa de declividades elaborado, o qual tem por base as linhas de cota naturais do terreno. Acredita-se que, por este motivo, é possível que exista um grande número de cortes e, consequentemente, de depósitos que não podem ser deduzidos a partir do mapa de declividades. Também são observados diversos depósitos de solo lançados, com mais de $50 \%$ de solo na matriz, composto também por lixo e entulho. Entre os depósitos identificados, foram observadas alturas que variam de 1 a $2 \mathrm{~m}$ e prevalece a inclinação de $90^{\circ}$. Estes depósitos, além de serem formados pelo material retirado na execução dos taludes de corte, são produtos do retrabalhamento do depósito mobilizado pelo deslizamento. A concentração de água pluvial e/ou servida em superfície induzida pela ocupação é o vetor tecnogênico mais presente no setor. O vazamento de tubulações foi pouco observado, e o lançamento de água servida em superfície e a presença de fossas não foram observados. O setor $4 \mathrm{~B}$ apresenta uma característica única, pois aqui houve a ocorrência de um grande deslizamento no ano de 1994, junto à rua Conde de Itaguaí, devido ao rompimento de uma adutora de água, que mobilizou grande quantidade de solo, lixo e entulho, ocasionando mudanças na topografia natural do terreno, aumentando sua inclinação. Não houve vítimas neste evento, pois o deslizamento foi gradativo, com a população percebendo a movimentação horas antes da deflagração do processo. A maioria dos cortes e depósitos executados no setor encontra-se sobre este depósito, ou são produtos do retrabalhamento do mesmo. A maioria dos depósitos presentes no setor apresenta sinais de rastejo, e um dos cortes já apresentou uma ruptura 
planar rasa no ano de 2007, com destruição parcial de uma moradia de madeira. Os condicionantes geológicogeotécnicos predisponentes e o nível de intervenção no setor 4B indicam alta potencialidade para 0 desenvolvimento de processos de deslizamento. Os cortes e depósitos deste setor apresentam suscetibilidade à deflagração de processos de instabilidade, a qual está relacionada à presença de um grande depósito no setor, ao porte das feições e aos depósitos sobre ou no próprio depósito pretérito. Outro fator importante é a tipologia das moradias, em sua maioria, construídas em madeira, além da presença de vielas sem pavimentação, o que auxilia a infiltração de água, acelerando os processos de instabilização. As condições observadas atingem alto grau de probabilidade de ocorrência de processos de instabilização. Mantidas as condições existentes, é possível a ocorrência de eventos destrutivos durante episódios de chuvas intensas e prolongadas, no período de um ano.

O setor 5B contempla o segundo maior talude de corte em extensão da área de estudo, com aproximadamente $10 \mathrm{~m}$, além de cortes menores e depósitos de solo lançados contendo lixo e entulho. Os taludes de corte têm alturas variando entre $1,7 \mathrm{~m}$ e $4 \mathrm{~m}$. $\mathrm{O}$ talude com maior altura no setor, variando de 2 a $4 \mathrm{~m}$, apresenta a maior extensão. Ocorrem taludes menores, com uma média de altura de $2 \mathrm{~m}$ e $90^{\circ}$ de inclinação. Os cortes foram executados para ampliação dos terrenos e construção das moradias, em meio a depósitos de solo lançados, contendo lixo e entulho na sua composição. Os depósitos de solo lançados do setor apresentam mais de $50 \%$ de solo em sua matriz, além de lixo e entulho. Nos depósitos identificados, foram observadas alturas que variam de $0,5 \mathrm{~m}$ a $1,7 \mathrm{~m}$, prevalecendo a inclinação de $90^{\circ}$. A maioria deles apresenta feições de saturação. A concentração de água pluvial e/ou servida em superfície induzida pela ocupação e o vazamento de tubulações são os vetores tecnogênicos mais presentes no setor. O lançamento de água servida em superfície também foi observado, o que indica a presença de água no setor. Não foi observada a presença de fossas. O setor $5 \mathrm{~B}$ teve a ocorrência de dois eventos. O primeiro em meados de 2007, quando um depósito de solo lançado, com altura entre 0,5 e $1 \mathrm{~m}$, rompeu após fortes chuvas, destruindo uma moradia de um cômodo, que havia sido construída sobre o mesmo, sem causar vítimas. No segundo evento, também em 2007, ocorreu a ruptura e desagregação de um corte executado em depósito de solo lançado, contendo lixo e entulho. Este setor apresenta alta suscetibilidade à ocorrência de processos de instabilização, principalmente devido ao grande número de depósitos tecnogênicos. Além deste fator, observou-se um elevado número de vazamentos e alta concentração de água pluvial ou servida. Os condicionantes geológico-geotécnicos predisponentes e o nível de intervenção no setor 5B são de alta potencialidade para o desenvolvimento de processos de instabilidade. As evidências de instabilidade são significativas. Mantidas as condições existentes, é possível a ocorrência de eventos destrutivos durante episódios de chuvas intensas e prolongadas, no período de um ano.

A análise destes dados possibilitou a identificação de cinco setores de risco distintos, sendo: grau de risco baixo para o setor $1 \mathrm{~B}$, risco muito alto para o setor $2 \mathrm{~B}$, risco médio para o setor $3 \mathrm{~B}$, risco alto para o setor $4 \mathrm{~B}$ e risco alto para o setor $5 \mathrm{~B}$.

\section{Análise comparativa entre o mapeamento com e sem a aplicação da proposta de classificação do Tecnógeno}

A Carta de Risco A (figura 2) foi elaborada a partir do método usual para mapeamento de risco geológico de deslizamentos, segundo o Ministério das Cidades/Instituto de Pesquisas Tecnológicas (2007), o qual levou em conta a análise da base topográfica da área de estudo, o modelo digital de elevação, a carta de declividades e as investigações geológico-geotécnicas de superfície. A análise e a inter-relação destes dados possibilitaram a identificação de três setores de risco distintos, sendo: grau de risco baixo para o setor $1 \mathrm{~A}$, risco muito alto para o setor $2 \mathrm{~A}$ e risco médio para o setor 3A.

A Carta de Risco B (figura 3) foi elaborada segundo método que leva em conta a análise da base topográfica da área de estudo, o modelo digital de elevação e a carta de declividades, como no método usual, e inclui a análise do mapeamento das feições, depósitos e vetores tecnogênicos, dos eixos de escoamento superficiais da área, da aplicação da proposta para classificação do tecnógeno e da carta de setorização do tecnógeno. A análise destes dados possibilitou a identificação de cinco setores de risco distintos, sendo: grau de risco baixo para o setor $1 \mathrm{~B}$, risco muito alto para o setor $2 \mathrm{~B}$, risco médio para o setor $3 \mathrm{~B}$, risco alto para o setor $4 \mathrm{~B}$ e risco alto para o setor $5 \mathrm{~B}$.

O setor $1 \mathrm{~B}$, da Carta de Risco B, apresenta limite semelhante ao setor $1 \mathrm{~A}$ da Carta de Risco A, ambos com grau de risco baixo, à exceção da porção nordeste, a qual foi incorporada ao setor $5 \mathrm{~B}$, com grau de risco alto (figuras 2 e 3 ).

A coincidência dos limites entre estes setores indica que o mapeamento do tecnógeno, realizado com maior detalhe que as investigações geológico-geotécnicas, não identificou nenhuma feição, depósito ou vetor tecnogênico que pudesse gerar modificações significativas na topografia e condições de estabilidade originais do terreno, o que poderia levar ao aumento da suscetibilidade à ocorrência de processos de instabilização e, portanto, aumentar o grau de risco do setor.

O setor $2 \mathrm{~B}$, da Carta de Risco $\mathrm{B}$, apresenta limite idêntico ao setor 2A, da Carta de Risco A, ambos com grau de risco muito alto (figuras 2 e 3 ).

É esperado que setores classificados com grau de risco muito alto pelo método usual apresentem o mesmo grau quando analisados em conjunto com o tecnógeno. A presença do tecnógeno tende a aumentar 
o grau de risco dos setores. Como o método usual indicou o grau máximo de risco, a presença do tecnógeno vem a confirmar essa análise. Nas investigações geológico-geotécnicas, o tecnógeno é tratado como parâmetro de uso e ocupação do solo. Porém, como este é o setor que apresenta a maior concentração de eixos antrópicos de escoamento superficial, o mais alto e mais extenso talude de corte, os depósitos mais diversificados em termos de gênese de formação e de maior altura, a presença do tecnógeno é muito significativa.

Isto esclarece porque este setor apresentava o grau de risco mais elevado mesmo sem a análise do tecnógeno, pois, apesar de o mapeamento geológico-geotécnico ser menos detalhado, seria difícil que tais feições, depósitos e vetores tecnogênicos tão significativos não fossem notados.

O setor 3B, da Carta de Risco B, apresenta limite semelhante ao setor 3A, da Carta de Risco A, ambos apresentando grau de risco médio, à exceção do seu limite centro superior e limite nordeste, os quais foram incorporados, respectivamente, aos setores $4 \mathrm{~B}$ e $5 \mathrm{~B}$, ambos com grau de risco alto (figuras 2 e 3 ).

A identificação destes novos setores se deu devido ao fato de o mapeamento, a classificação e a setorização do tecnógeno identificarem feições, depósitos e vetores tecnogênicos com características diferenciadas nestes novos setores, que não refletem a média das características observadas no setor 3B.

O setor $3 \mathrm{~B}$ apresenta cortes e depósitos de altura média, e os eixos de escoamento antrópico, apesar de estarem presentes em quase todo setor, não causam grandes problemas, pois, em sua maioria, são paralelos às curvas de nível, o que gera a diminuição do gradiente hidráulico das águas provenientes de montante.

O setor 4B, da Carta de Risco B, foi identificado a partir da análise do tecnógeno. Este setor é parte do setor 3A, da Carta de Risco A (figuras 2 e 3).

A criação deste setor se deve ao fato de 0 mapeamento do tecnógeno ter identificado diversos cortes e depósitos com alturas elevadas e inclinação predominante de $90^{\circ}$. A presença destas feições se deve ao fato de este setor estar locado sobre a cicatriz e o antigo depósito de material mobilizado por um grande deslizamento ocorrido na área, no ano de 1994. A cicatriz, de grande extensão, aumentou a declividade deste setor. Além da alta declividade, os cortes e os novos depósitos são produtos do retrabalhamento do material mobilizado, o que aumenta a suscetibilidade de ocorrência de processos de instabilidade. A área deste setor, antes de iniciada a ocupação, era uma cabeceira de drenagem, por onde passava o eixo de escoamento superficial natural. Hoje, com a ocupação, além de a morfologia natural gerar a concentração de água no centro do setor, observam-se três eixos antrópicos, que direcionam as águas superficiais em direção à base do material mobilizado pelo deslizamento.
O setor 5B, da Carta de Risco B, também foi identificado a partir da aplicação da análise do tecnógeno. Este setor é uma fusão da parte nordeste do setor $1 \mathrm{~A}$ e de um trecho da porção nordeste inferior do setor 3A, da Carta de Risco A (figuras 2 e 3).

A criação deste setor se deve ao fato de o mapeamento do tecnógeno ter identificado diversos cortes e depósitos com alturas elevadas e inclinação predominante de $90^{\circ}$. Além disso, foi identificada a deflagração de dois processos de instabilidade durante esse mapeamento. Este setor encontra-se em expansão, e é grande o número de intervenções que foram executadas nos dois últimos anos, como a escavação de cortes e a construção de aterros. Apesar da pequena quantidade de eixos antrópicos de escoamento no setor, as águas superficiais o atingem com grande energia, pois observa-se uma viela, praticamente retilínea, no sentido noroeste-sudeste, a qual se direciona para o topo do setor, onde a água é distribuída por mais três vielas até a base deste.

\section{Conclusões}

A revisão bibliográfica mostrou a importância dos estudos do tecnógeno para o entendimento da dinâmica dos movimentos de massa (deslizamentos, principalmente). Quando a ocupação dos espaços urbanos se dá de maneira desordenada, por populações pobres, sem o uso de conhecimentos técnicos, o tecnógeno produzido terá papel fundamental na deflagração dos deslizamentos. Observou-se também que as metodologias para a elaboração de cartas de risco de deslizamento não levam em conta a análise do tecnógeno enquanto parâmetro importante na determinação dos níveis de risco. Da mesma forma, as classificações existentes para o tecnógeno são voltadas para os depósitos e sua gênese, não contemplando aspectos importantes como feições ou vetores tecnogênicos, além do porte dessas intervenções, os quais são decisivos no estabelecimento dos níveis de risco.

Um dos objetivos deste trabalho foi, além da proposta de classificação, comparar os resultados das cartas de risco elaboradas pelo método usual, e com a inserção da análise do tecnógeno. Assim, as propostas de elaboração de duas cartas de risco e de uma proposta de classificação do tecnógeno foram realizadas, tendo como área-piloto a favela do Real Parque, em São Paulo.

A proposta de uma nova classificação para o tecnógeno surgiu, pois entre as classificações observadas, nenhuma apresentou um enfoque direto relacionando à questão do risco geológico versus tecnógeno. Sua inserção no método usual apresentou bons resultados, enfatizando a importância da análise do tecnógeno nas questões relacionas, principalmente, aos riscos de deslizamento.

A Carta de Risco A foi elaborada com base no método usual, utilizando a análise da base topográfica da área, fotografias aéreas, modelo digital de terreno, carta de declividade e as investigações geológico- 
geotécnicas de campo, isentando-se de considerar informações e observações mais detalhadas sobre o tecnógeno presente na área de estudo. Esta carta resultou na identificação de três setores (1 A, 2 A e 3 A).

A proposta de classificação do tecnógeno foi elaborada com o intuito de ser utilizada em áreas de assentamentos urbanos precários, tendo como base três grupos distintos: feições tecnogênicas, depósitos tecnogênicos e vetores tecnogênicos. Sua aplicação na área-piloto foi de grande valia, auxiliando na elaboração da setorização do tecnógeno e, consequentemente, na Carta de Risco B.

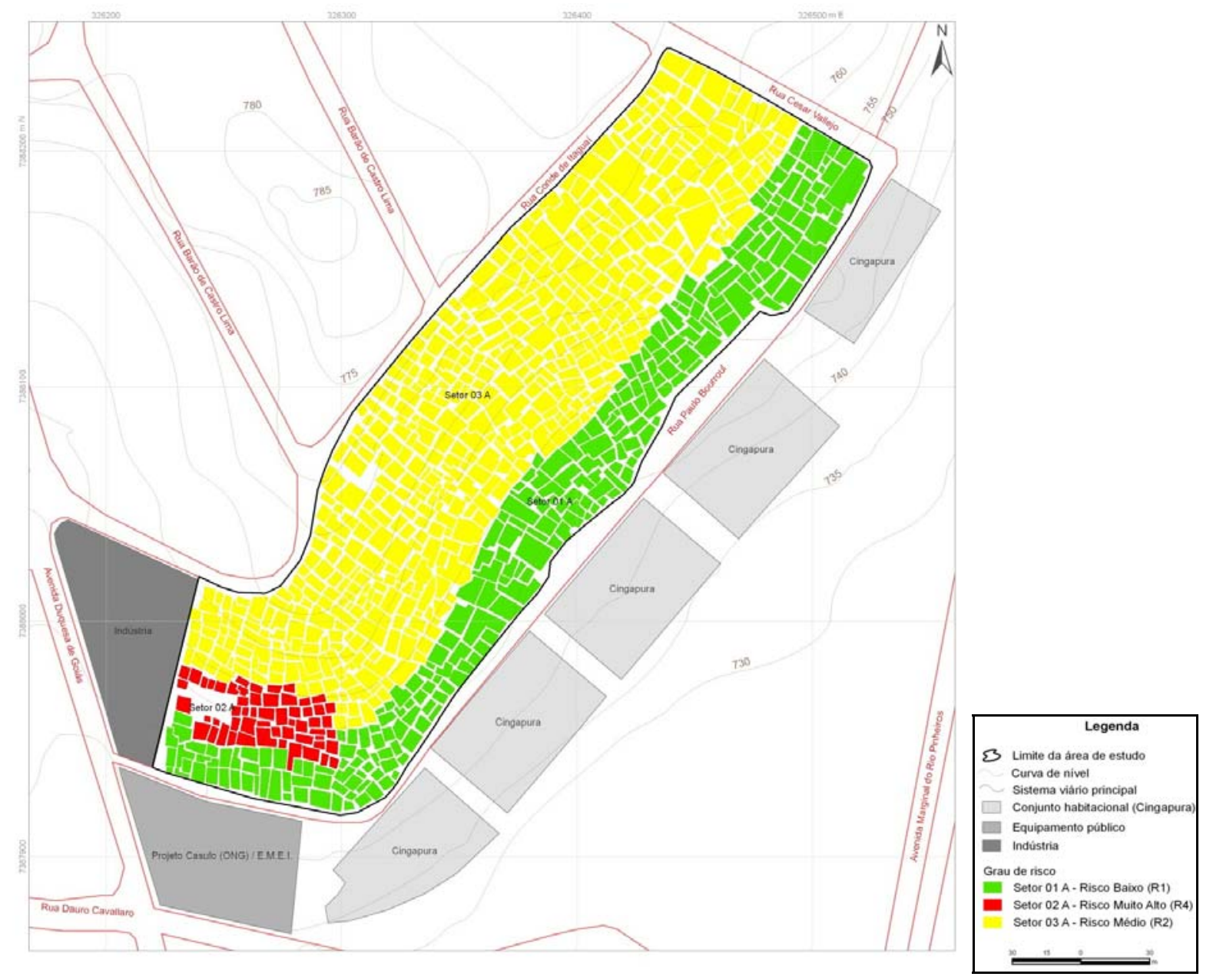

Figura 2: Carta de Risco A

A Carta de Risco B foi elaborada a partir do método usual de elaboração de cartas de risco, porém com o acréscimo da análise do tecnógeno - ou seja, com acréscimo do mapeamento de feições, depósitos e vetores tecnogênicos, da análise da carta de eixos de escoamento superficial e da setorização do tecnógeno com a aplicação da proposta para classificação do tecnógeno. Esta carta resultou na identificação de cinco setores (1 B, 2 B, 3 B, 4 B e 5 B).

A inserção da análise do tecnógeno na elaboração da carta aperfeiçoou a análise do risco de deslizamento, o que se observa pela identificação de mais dois setores na Carta de Risco B, os quais apresentam graus de risco mais elevados do que aqueles observados pelo método usual, na Carta de Risco A. Isto se deve ao aumento do detalhe nas observações de campo, o que possibilita a identificação de novos setores, enfatizando-se a necessidade de um olhar mais crítico, sendo imprescindível a análise conjunta dos condicionantes geológico-geotécnicos e do tecnógeno, pois somente desta maneira teremos uma representação fidedigna dos riscos relativos a deslizamentos presentes na área de estudo.

Finalmente, ainda se pode considerar que as Cartas de Risco obtidas têm um componente qualitativo importante, o que pode comprometer sua reprodutibilidade. Como uma pesquisa ainda a ser realizada, poderiam ser analisados os graus de estabilidade dos taludes naturais, de corte e mesmo de depósitos, na busca por parâmetros mais quantitativos. 
Antropoceno - Tecnógeno

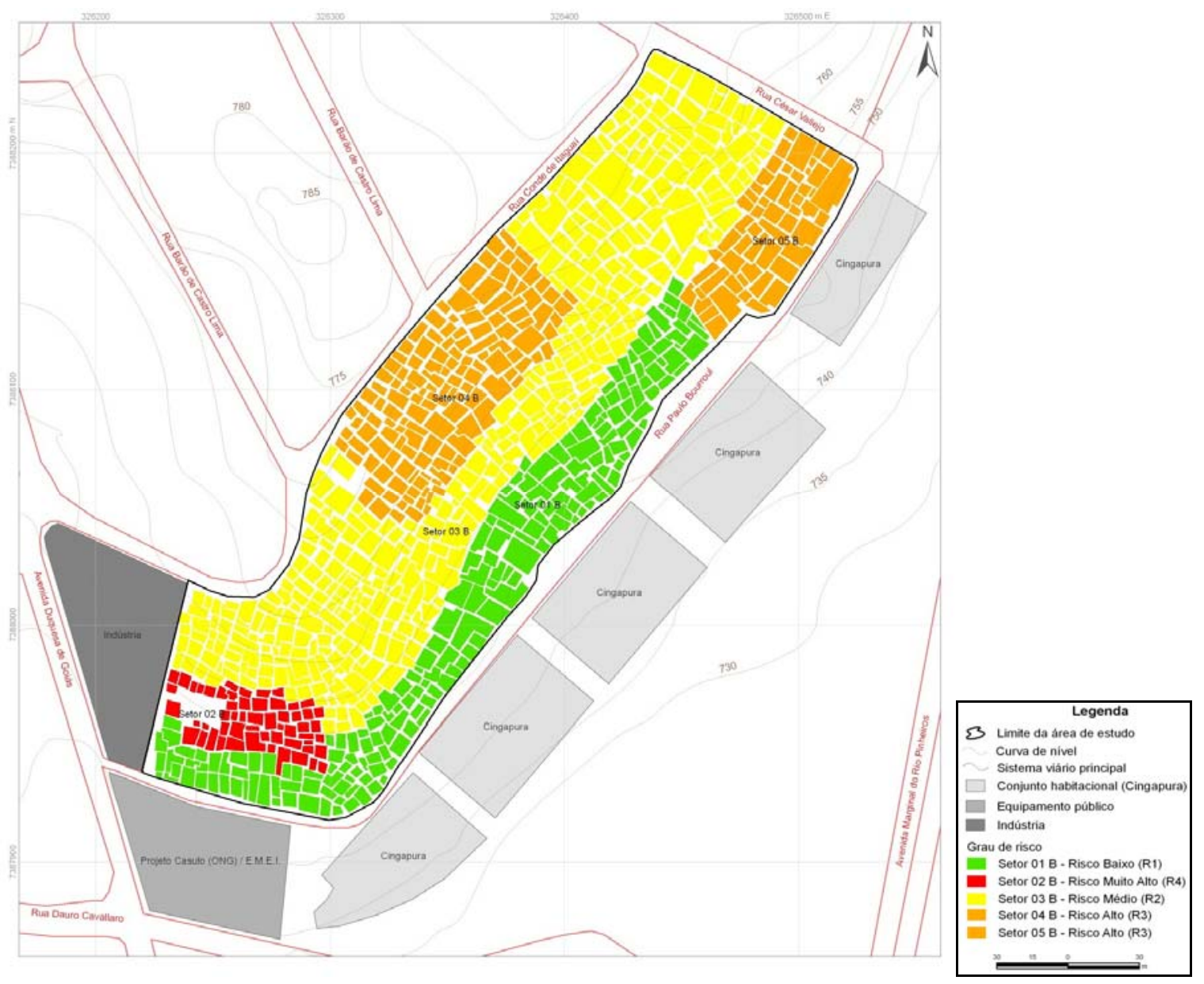

Figura 3: Carta de Risco B

\section{Referências}

Bertê A.M.A., Troleis A., Suertegaray D.M.A. 2000. O Tempo da Ação Humana e suas Transformações. Anais do III Simpósio de Geomorfologia. V. 1. Campinas.

Bertê A.M.A. 2004. Depósitos tecnogênicos e planejamento urbano: o aterro sanitário da zona norte de Porto Alegre - RS/Brasil. Anais do V Encontro Nacional de Geomorfologia, 1: 1-15.

Cerri L.E.S., Amaral C.P. 1998. Riscos Geológicos. In: Oliveira A.M.S., Brito S.N.A. (Eds). Geologia de Engenharia. ABGE, São Paulo. Cap 18, 301-310p.

Chemekov Y.F. 1983. Technogenic deposit. Abstracts of XI INQUA Congress, 3:62. Moscow.

Fanning D.J., Fanning M.C.B. 1989. Soil: morphology, genesis and classification. John Wiley \& Sons, New York, 395p.

Fujimoto N.S.V. 2000. Análise ambiental urbana na área metropolitana de Porto Alegre, RS: proposta teórica e metodológica. Tese de Doutorado. Pós-Graduação em Geografia, Departamento de Geografia da Faculdade de Filosofia, Letras e Ciências Humanas, Universidade de São Paulo, 238p.

Horn Filho N.O. 2003. Setorização da Província Costeira de Santa Catarina em base aos aspectos geológicos, geomorfológicos e geográficos. GEOSUL, v.18, 35:71-98.

Ministério das Cidades, Instituto de Pesquisas Tecnológicas. 2007. Mapeamento de Riscos em Encostas e Margem de Rios. Ministério das Cidades, Brasília, 176p.

Mirandola F.A. 2003. Zoneamento de risco geológico na área da favela Real Parque, São Paulo. Monografia (Trabalho de Formatura). Graduação em Geologia, Instituto de Geociências, Universidade de São Paulo, 120p.

Nolasco M.C. 2002. Registros geológicos gerados pelo garimpo: Lavras Diamantinas - BA. Tese de Doutorado. Pós-Graduação em Geologia, Instituto de Geociências, Universidade Federal do Rio Grande do Sul, 316p.

Nolasco M.C., Oliveira A.M.S. 2001. Registros geológicos tecnogênicos e suas conseqüências: um olhar sobre a ação geológica do homem. Anais do V Congresso Quaternário de Países de Línguas Ibérricas, 1: 297-300.

Nolasco M.C., Oliveira A.M.S. 2000. Tecnogenic actions and records; a proposal of classification. Resúmenes II Congresso Latinoamericano de Sedimentología, 1:133p.

Oliveira A.M.S. 1990. Depósitos tecnogênicos associados à erosão atual. Anais do VI Congresso Brasileiro de Geologia de Engenharia, 1:411-415.

Oliveira A.M.S., Brannstrom C., Nolasco M.C., Peloggia A.U.G., Peixoto M.N.O., Coltrinari L. 2005. Tecnógeno: registros da ação geológica do homem. In: Souza C.R.G., Suguio K., Oliveira A.M.S., Oliveira P.E. (eds) Quaternário do Brasil. Holos, Ribeirão Preto, Cap.17, 363-378p.

Peloggia A.U.G. 1996. Delineação e aprofundamento temático da geologia do tecnógeno no município de São Paulo: as consequências da ação do homem sobre a natureza e as determinações geológicas da ação humana em suas particularidades referentes à precária ocupação urbana. Tese de Doutorado. Pós-Graduação em Geologia, Instituto de Geociências, Universidade de São Paulo, 262p.

Peloggia A.U.G. 1999. Sobre a classificação, enquadramento estratigráfico e cartografação dos depósitos tecnogênicos. In: Prefeitura do Município de São Paulo (eds) Artigo em manual técnico: Estudos de Geotécnica e Geologia Urbana (I). Manual Técnico 3 GT - GEOTEC, São Paulo, 42p.

Peloggia A.U.G. 2003. O problema estratigráfico dos depósitos tecnogênicos. Anais do IX Congresso Brasileiro de Estudos do Quaternário, 1 CD-ROM. 


\section{Antropoceno - Tecnógeno}

Peloggia A.U.G., Oliveira A.M.S. 2005. Tecnógeno: um novo campo de estudos das geociências. Anais do X Congresso Brasileiro de Estudos do Quaternário, 1 CD-ROM.

Ross J.L.S. 1992. O registro cartográfico dos fatos geomorfológicos e a questão da taxonomia do relevo. Revista do Departamento de Geografia, 6:17-29.

Ter-Stepanian G. 1988. Beginning of the Tecnogene. Bulletin of the international Association of Engineering Geology, 38:133-142.

Zorzato D., Peloggia A.U.G. 2000. Análise do risco geológico urbano no Município de São Paulo na década de 1990. Secretaria da Habitação e Desenvolvimento Urbano (Superintendência de Habitação Popular), Manual Técnico: Estudos de geotécnica e geologia urbana (II), 45p

Recebido 14 de dezembro de 2013 Aceito 06 de junho de 2014 